\title{
PRAGMATIC COMPETENCE AND THE CEFR: PRAGMATIC PROFILING AS A LINK BETWEEN THEORY AND LANGUAGE USE
}

\section{INTRODUCTION}

The goal behind the creation of the Common European Framework of Reference for Languages (CEFR) was to provide a comprehensive description of "what language learners have to learn to do in order to use a language for communication and what knowledge and skills they have to develop so as to be able to act effectively" (CEFR 2001: 1). Most notably, it "defines levels of proficiency, which allow learners' progress to be measured at each stage of learning" (CEFR 2001: 1), i.e. the well-known and widely-used proficiency scale, ranging from A1 ("Breakthrough") to C2 ("Mastery"), that is intended to provide "objective criteria for describing language proficiency" (CEFR 2001: 1). Taking this twofold perspective, the CEFR both sets a common standard for the goals of language education, directed at teachers and learners, and offers an inventory of tools for assessing the progress of learners within this framework, in language testing and certification.

Despite its practical, instrumental and explicitly non-obligatory nature, the CEFR nonetheless represents a theory about the scope, structure and contents of language competence, especially given its claims to comprehensiveness, as far as realistically attainable ${ }^{1}$ (CEFR 2001: 7). Furthermore, it is bound to reify this theory via the influence it demonstrably exerts on institutional practices in language teaching, assessment and certification (see Martyniuk and Noijons 2007). Underlining its influence beyond the provision of proficiency scales, the English Profile research group similarly comments that the CEFR "has underpinned a particular approach to language learning, as the one most commonly recommended, or expected, in language teaching today" (Introductory Guide to the Common European Framework of Reference [CEFR] for English Language Teachers: 2).

What kinds of knowledge and competence does a language learner have to acquire, in order to become proficient in another language? There is ample evidence gathered

* Author's addresses: Institut für Anglistik, Amerikanistik und Keltologie, Bonn Applied English Linguistics, Regina-Pacis-Weg5, 53113 Bonn, Germany. E-mails: k.schneider@uni-bonn.de, pawel.sickinger@uni-bonn.de.

1 See North (2014: 230), however, for a considerably weaker interpretation of the CEFR's comprehensiveness and authority. 
in pragmatics and applied linguistics, which we will briefly touch upon in section 2 below, that learning a second or foreign language goes well beyond acquiring additional semantic and grammatical categories and distinctions. Indeed, the aim of language learning ought to go beyond acquiring the competence to produce grammatical sentences in the target language. Most importantly, it should enable learners to produce utterances that are considered functionally and socially appropriate by native speakers, in any given context. This is only indirectly correlated with the correctness of the linguistic forms produced, and certainly not exhaustively covered by a list of set phrases or vocabulary items, to be memorized and reproduced by learners. The two domains are best-considered as two distinct parts of (developing) language competence, in the sense that appropriate communicative behaviour depends on the interaction between both competences. Learners of a language will only then successfully communicate in the target language if both are available, i.e. the necessary inventory of linguistic forms and structures, and knowledge about their appropriate, purposeful use in context. The latter ability is what we would like to call "pragmatic competence" (see section 2).

Fortunately, as far as the CEFR's model of language competence is concerned, potential worries about an extensive bias towards formal aspects of language are unwarranted. The view of language use and learning it endorses is explicitly action-based, focusing on "acts of speech [that] occur within language activities" which, in turn, "form part of a wider social context" (CEFR 2001: 9). Correspondingly, the basic model of communicative language competence presented in the CEFR's main document distinguishes three major domains of competence: linguistic, sociolinguistic and pragmatic competences (CEFR 2001: 13f), a delineation that is notably similar to, and clearly informed by, linguistic theories of communicative competence (cf. section 2).

We will argue that, while this notably pragmatic perspective on language embraced by the CEFR is laudable, at the same time, it offers little guidance in how to implement this in practice, which is in stark contrast to the wealth of material available for linguistic competence proper, i.e. vocabulary and grammar. While this is understandable, given the lack of tradition, experience and, in many cases, interest for this fundamental aspect of language proficiency in the education system (cf. Lázár et al. 2007: 5), it begs the question how to attune common practice to the CEFR's vision. Before addressing this issue, however, we will first briefly delineate the concept of pragmatic competence as discussed in linguistics (section 2), and why we see it as a quintessential part of language learning that needs to be carried over from the realm of theory and policy to the actual practice of language teaching, testing and certification (section 3).

\section{NOTIONS OF PRAGMATIC COMPETENCE}

Pragmatic competence has been defined in a number of different ways (cf., e.g., Bachman 1990; Fraser 2010; Ifantidou 2010; Taguchi 2011), and the same applies to pragmatic ability, which is a term sometimes employed as a synonym (cf., e.g., McNamara/Roever 1996; Yule 1996; Yamashita 2008). Attempts to reach a consensus in defining pragmatic competence still continue, as shown by its central role in a number 
of recent publications (see e.g. Kasper/Ross 2013; Kecskes 2014: Chapter 3). Below we review two definitions which are immediately relevant to our purposes.

The first definition of pragmatic competence to be discussed was formulated by Jenny Thomas in 1983. In this definition, Thomas contrasts "pragmatic competence" with what she calls "grammatical competence". These two types of competence combine into a speaker's "linguistic competence". In other words, a speaker's overall language competence comprises two complementary components, or "sub-competences", which are here called "grammatical" and "pragmatic", respectively.

A speaker's 'linguistic competence' would be made up of grammatical competence ('abstract' or decontextualized knowledge of intonation, phonology, syntax, semantics, etc.) and pragmatic competence (the ability to use language effectively in order to achieve a specific purpose and to understand language in context) (Thomas 1983: 92).

In this context, the term "grammatical" is, perhaps, misleading as it traditionally refers to morpho-syntax exclusively. In Thomas' conception, however, it is used in a much broader sense. In her view, "grammatical competence" includes not only knowledge of syntax, but also knowledge of phonology and intonation on the one hand, and knowledge of semantics on the other (morphology is not mentioned explicitly in the above definition, but is probably subsumed under "etc."). Moreover, this type of linguistic competence is abstract, in that it is independent of context. Pragmatic competence, by contrast, is context-sensitive. It concerns the production, as well as the comprehension of language relative to social situations. Furthermore, and most importantly, pragmatic competence is the ability to use linguistic means for achieving particular communicative goals. If taken literally, then pragmatic means related to action, and action can be defined as "intentional behaviour". Speakers have intentions. They pursue communicative goals by employing the linguistic devices specified and stored in what Thomas calls "grammatical competence". Her view is perfectly compatible with Leech's conception of linguistics (Leech 1983). He maintains that the nature of language can only be adequately understood if two complementary domains are examined, along with the interaction between them. These two domains are grammar and pragmatics, which are Leech's synonyms for the language system and for language use, respectively (cf. Leech 1983: 4).

The author of the second definition we wish to discuss posits that pragmatic competence, in turn, includes two component parts or sub-competences. Liu (2004: 14) writes:

[...] pragmatic competence consists of (at least) two components: knowledge of a pragmatic system, and knowledge of its appropriate use. The former provides the range of linguistic options available to individuals for performing various acts, while the latter enables them to select the appropriate choice given a particular goal in a particular setting.

These two components, i.e. "knowledge of a pragmatic system" and "knowledge of its appropriate use", reflect a pair of concepts originally introduced, again, by Thomas (1983), and popularized by Leech (1983). The terms they use are pragmalinguistics and 
sociopragmatics. Pragmalinguistics specifies the respective devices available in a language to perform a particular communicative act, whereas sociopragmatics details the choices to be made in a given context. According to Leech (1983: 10-13), pragmalinguistics is the interface of pragmatics with the language system (for which Leech 1983 uses the term grammar) and, hence, language-specific. Sociopragmatics, by contrast, is the interface of pragmatics with sociology-it is not language-specific, but culturespecific. Thus, pragmalinguistic competence involves, for example, knowledge about the syntactic constructions and lexical items which can be used in a given language to pay a compliment, while sociopragmatic competence involves knowing what is considered appropriate in a given culture (i.e. society, social group or community of practice), specifically who may compliment whom, on what, and how (cf., e.g., Holmes/Brown 1987). Sociopragmatic competence, thus, seems to roughly correspond to sociolinguistic competence as characterized e.g. by Regan et al. (2009), which is the term also used to delineate this aspect of communicative competence in the CEFR.

Liu's explicit mentioning of "acts" in the definition above illustrates that pragmatic competence is often reduced to the speech act level. In our view, however, this level is only one among several levels of discourse (cf., e.g., Schneider/Barron 2008a: 19-21; also Schiffrin 1987: 21-29; Jucker 2008; Kasper/Ross 2013). In this perspective, pragmatic competence includes not only the ability to perform speech acts, but also, for instance, the ability to react to speech acts, to combine speech acts into sequences, and negotiate pragmatic meaning and identities across such sequences, to open and close a conversation, to take turns and hold the floor, to introduce, maintain and terminate topics, and to employ discourse markers. In short, in this less prototypical and less reductionist, but more encompassing and more adequate view, pragmatic competence equips language users to fully participate in discourse on all relevant levels.

As we have already mentioned above, the basic notion of pragmatic competence, delineated via these examples from the linguistic literature, is fairly compatible with the CEFR's description of communicative competence and its subcomponents. At the same time, it considerably overlaps with various notions of intercultural (communicative) competence, as proposed e.g. in Byram 1997, Lázár et al. 2007 and the INCA project (Byram 2004), specifically regarding the dimension of know-how or savoirfaire. Against the background of this strong consensus, it is rather surprising that the implementation of this novel perspective on language learning and education has not been pursued more emphatically and rigorously.

Before discussing this issue in the following section, however, we would like to emphasize that pragmatic competence is of special importance in language learning, as low competence in this area can be a critical source of miscommunication and, specifically, of intercultural misunderstandings. It is well-attested that native speakers expect learners to make lexical and grammatical mistakes. This is considered normal in the acquisition process and is, therefore, tolerated to a certain degree (see e.g. Thomas 1983: 97). At the same time, native speakers assume that learners observe the same pragmatic norms, i.e. that they behave in the same way that native speakers do. Native speakers generally believe, for instance, that all humans apologize for the same kinds of offense. 
In essence, they believe that notions of politeness and appropriateness are universally shared. Therefore, violating pragmatic norms is not, as a rule, tolerated (see e.g. Bardovi-Harlig/Mahan-Taylor 2003). As has been shown in previous studies, violations of these norms are often interpreted as rude behaviour, or attributed to personality flaws (cf., e.g., Barron 2003; O'Keeffe et al. 2011). However, more often than not, learners do not intentionally violate target culture norms, they may merely follow the pragmatic norms of their native culture (cf. O'Keeffe et al. 2011: 101). In this regard, we would like to emphasise the negative consequences this state of affairs has for learners, their learning process and the development of pragmatic competence in their foreign language. Given a native speaker's perception of a learner's violation of pragmatic norms of the target culture, learners are not likely to receive any helpful feedback, in cases of such pragmatic failure (cf. Thomas 1983: 96-97). Considering divergence from one's own pragmatic norms as a personal deficit in the learner generally precludes corrections of unexpected communicative behaviour, since corrections of this kind would be highly face-threatening and will, therefore, be avoided by the majority of interactants. This situation makes the inclusion of explicit guidance in developing pragmatic competence in the course of foreign language education all the more important for learners (cf. Thomas 1983: 109-110).

\section{THE NEED TO EXTEND THE CEFR'S SCOPE}

Both the models of linguistic competence reviewed above and the one at the core of the CEFR are descriptions of fundamental structures at a very general level, that - although useful and necessary as an underlying framework - stop short of linking their claims to the level of actual language use. Recalling the CEFR's role as providing guidance to practitioners, with the aim of grounding their actual practice in a common framework, thereby enabling consistency, comparability and a shared standard of quality across institutions and nations, this state of affairs seems critical. In our view, the main problem is that the transition from general guidelines to application is still in the hands of individual practitioners - necessarily without any direct influence by the CEFR, in this part of the process. This means that individual interpretations of CEFR texts and descriptors can, and most likely will, lead to a highly-diverse range of realisations in practice that, nonetheless, suggest direct comparability, by referring back to the common framework. Anthony Green also points to this problem, noting that customisation in practice, although generally welcomed by the CEFR, "is likely to work against the comparability of outcomes from programmes purportedly situated at the same level" (Green 2012: 60).

A 2006 survey on the use and reception of the CEFR correspondingly found that, against the background of an overall strongly-positive evaluation, informants mentioned both a "lack of precision in some of the level descriptors" and a general "difficulty of linking tests to the CEFR" as pressing issues (Martyniuk/Noijons 2007: 7). The Council of Europe, on its website, similarly comments that "for operators, textbook authors and teachers, the specification set out in the CEFR may appear excessively 
broad"2, primarily due to the generality of the framework, and points to the need for "transpositions of the CEFR into a given language" to remedy this problem ${ }^{3}$.

A potential solution has been developed in the form of so-called reference level descriptions (RLDs) that are now being compiled in an attempt to identify "the forms of a given language (words, grammar, etc.), mastery of which corresponds to the communicational, socio-linguistic, formal and other competences defined by the CEFR", on all six proficiency levels, for national and regional languages ${ }^{4}$. A number of different research groups are currently pursuing this goal for individual languages, with the English RLD component (the one most relevant to our work) being developed by the English Profile program, based in Cambridge. The English Profile is a "collaborative programme endorsed by the Council of Europe, designed to create a "profile" or set of Reference Level Descriptions for English"s that comprises several individual research projects, working towards "reliable, detailed description of the actual learner English that is typical of each CEFR level" (Introductory Guide to the Common European Framework of Reference [CEFR] for English Language Teachers: 8). Following the CEFR's basic structure, the English Profile has first started to develop RLDs for the domain of vocabulary, a project that is now completed and accessible online, as a resource for teachers. A second line of research on the gradual improvement of learners' grammatical competence, mapped onto the CEFR proficiency scale, is also in an advanced stage of development (Introductory Guide to the Common European Framework of Reference [CEFR] for English Language Teachers: 8). Notably, however, these two main lines of research only cover what is comprised under "linguistic competence" in the CEFR's model, with sociolinguistic and pragmatic competences not yet thoroughly covered. Although the English Profile already has a background in analysing language "functions", based on previous work in the so-called "T-series" (see Green 2012 for a review), this has not yet been operationalised for RLD-based systematic profiling on par with the vocabulary and grammar components.

Intensive discussion with English Profile members, over the course of three years, convinced us that the role of pragmatic competence (including the sociolinguistic component) in the CEFR is still critically underspecified, even though it is strongly emphasized in its programmatic view of a communicative linguistic competence. One of the problems with further developing this aspect of the CEFR is that it does not lend itself to a methodological approach that parallels what the English Profile has already achieved regarding RLDs for vocabulary and grammar. The main difference is that pragmatic aspects of language use and competence are less rigidly governed by common norms, are generally more context-sensitive, and can be less validly treated as "right" or "wrong", based on native speaker intuition (cf. Kecskes 2014: 62). This fundamental qualitative difference is acknowledged in the CEFR itself, where the lin-

2 https://www.coe.int/t/dg4/linguistic/dnr_EN.asp (accessed 10 July 2014).

3 https://www.coe.int/t/dg4/linguistic/dnr_EN.asp (accessed 10 July 2014).

$4 \mathrm{https}: / /$ www.coe.int/t/dg4/linguistic/dnr_EN.asp (accessed 10 July 2014).

5 http://www.englishprofile.org/ (accessed 10 July 2014). 
guistic competence subcomponent of communicative language competence is characterised as concerning various dimensions of "language as a system, independently of the sociolinguistic value of its variations and the pragmatic functions of its realisations" (CEFR 2001: 13). Furthermore, the CEFR explicitly acknowledges that the sociolinguistic and pragmatic components are less easily described in its standard format, i.e. generalised descriptor statements at each level of the scale. The authors concede that the "scaling of items for aspects of sociolinguistic competence proved problematic" (CEFR 2001: 121), and that it "is not feasible to develop illustrative scales for all the areas of competence implied when one talks of functional ability" (CEFR 2001: 128), in effect pointing out the incompatibility between abstract descriptor statements and the highly context-bound, functional aspects of language.

In our view, two challenges to the CEFR, in its current form, present themselves, as far as pragmatic competence is concerned ${ }^{6}$. On the one hand, a more coherent, less arbitrarily structured and principled treatment of pragmatic competence, on theoretical grounds, would help to further clarify its functional and structural role in a comprehensive model of communicative linguistic competence. On the other hand, this treatment of pragmatic competence has to amount to more than a mere theoretical essay - it has to become transitive towards, and ultimately grounded in, actual language use, e.g. in the form of reference level descriptions. When carried out thoroughly, the latter objective should naturally establish a link between general descriptions of linguistic competences, at the most abstract level, and the practical necessities and interests of practitioners involved in language testing, at the other end of the continuum.

\section{PRAGMATIC PROFILING}

We are currently pursuing these goals in the context of PRA.PRO (short for Pragmatic Profiling), which is an ongoing research project at the University of Bonn, Germany. There are two major project aims. One is to develop a more comprehensive and, perhaps more importantly, a more detailed definition of pragmatic competence than is currently available. Due to the methodological approach taken in the research project (described in more detail below), the resulting model can be expected to function both from a top-down perspective, informed by theoretical considerations, and a bottom-up perspective, that directly maps empirical data generated in the project onto the structure of the model. The other aim is to create an instrument for assessing pragmatic competence. Currently, we are primarily interested in assessing the pragmatic competence of foreign language learners and, specifically, of German learners of English. At a later stage, other areas of examination may be included, notably assessing the development of pragmatic competence in the native language of young children, and also measuring the pragmatic competence in patients suffering from a neurological disorder, such as Alzheimer's Disease (for earlier approaches, cf. e.g. Lamar et al. 1994; Ball 2000).

6 A similar point could be made regarding some of the more influential models of intercultural communicative competence (e.g. Byram 2004 and Lázár et al. 2007) but, regrettably, a detailed treatment of this issue is beyond the scope of this article. 
The profiles prominently mentioned in the project name refer to a set of pragmatic norms of communicative behaviour (in our use of the term this comprises both pragmalinguistic and sociopragmatic aspects) prevalent in the native speaker language community. For rather obvious methodological reasons, these norms cannot be directly observed or elicited, mainly due to the fact that native speakers, perfectly capable of consistently applying them in practice, do not necessarily have any access to, or awareness of, the underlying principles guiding their behaviour. Therefore, we have to resort to gathering behavioural and experimental data, the analysis of which, then, indirectly reveals the underlying norms. This is the basic methodological commitment behind our approach to profiling and comparing pragmatic competence in native speakers and learners, and ultimately testing it in learners. The "ideal" against which learner performance is to be measured has to be derived, inductively, from analysing native speakers' language production, not based on an a priori understanding of what appropriate communicative behaviour in a given language is according to a group of experts. Furthermore, to enable direct comparison between native speaker and learner profiles, their respective performances need to be elicited under rigidly-controlled conditions, so that an explicit measure of similarity and divergence is possible.

With these requirements in mind, data collection for PRA.PRO so far has been carried out using the Questionnaire on English Usage (QEU), a research instrument originally developed by Schneider and Barron (see e.g. Schneider 2005). It comprises a variety of communicative situations for eliciting utterance production in discourse production task (DPT) and dialogue completion task (DCT) format, as well as multiplechoice questions ${ }^{7}$. Data from native speakers of English has been collected in a number of varieties, including English English, American English, Canadian English and Irish English, with the aim of creating pragmatic profiles for each of these varieties.

This deliberate attempt to capture differences between varieties of English partly owes its existence to the fact that our work on pragmatic competence was developed from a variational pragmatics background (see e.g., Schneider/Barron 2008a), but we also deem it critical for foreign language learning, teaching and assessment (cf. Barron 2005). If learners are expected to (strategically) align their own communicative behaviour with native speaker behaviour in order to use their foreign language appropriately, the question arises regarding whose communicative and cultural norms they are supposed to adopt. Languages are not homogeneous wholes, but characterised by "orderly heterogeneity" (Weinreich et al. 1968: 100). It is a common misconception, especially in the context of language teaching and foreign language learning, that all native speakers of a language behave in the same way, and act uniformly under the same context conditions (cf. Kasper 1995; also Wierzbicka 1985). However, pragmatic variation in language use exists and occurs relative to such factors as region, social class, ethnicity, gender and age (cf., e.g., Schneider/Barron 2008a; Schneider 2012a). Pragmatic norms and language-use conventions differ not only across languages, but also across varieties of the same language, i.e. across social groups and communities of practice or, for short, across cultures.

7 For a more detailed description, see: http://www.linguistics.uni-bonn.de/questionnaire-on-englishusage-qeu/ 
In addition to the groups of native speakers mentioned above, German learners of English have been tested using the same questionnaire. Additionally, a version for German native speakers has been used for purposes of establishing a pragmatic profile for German, for example, to examine the learner data for hints at negative transfer from first language pragmatic norms. Lastly, a longitudinal study, repeatedly testing the same group of German school students during their stay abroad in Canada, has been carried out with the support of Stepin, a company organising study abroad and similar programmes in English-speaking countries around the world. This strand of the project attempts to track young learners' developing pragmatic competence when exposed to a native speaker environment over an extended time period (cf. Barron 2003 and Schauer 2009 for related empirical work on this topic).

While the data gathered from these different groups of speakers are still being evaluated, a number of selected aspects have already been analysed and covered in earlier publications. Schneider (2005), for example, investigated differences in the use of responses to thanks across English English, Irish English and American English, as part of the overarching attempt to characterise the pragmatic norms of different native speaker varieties of English. He successfully identified differences in pragmatic behaviour, especially concerning the influence of differing levels of formality within varieties. Focusing on the role of pragmatic and intercultural competence in second language education, Schneider (2008b) investigated small talk dialogues, elicited via a DPT task included in the QEU. Noting profound differences across varieties in this particular communicative scenario, he argues that the issue of pragmatic competence and variational differences needs to be properly addressed in second language teaching curricula. In Schneider 2008a, the same small-talk situation was analysed for a female subgroup of the overall population queried with the QEU, again including native speakers of English English, Irish English and American English. The findings show both strongly converging strategies within varieties and marked differences across varieties, a result that Schneider 2011 and 2012b interpret as indicating a reliance on underlying cultural models/behavioural scripts, which can be seen as "the very essence of pragmatic competence" (2011:32) in production, as well as comprehension.

Most recently, initial results from the longitudinal study on German students exposed to a native Canadian English environment over their time abroad have been presented at the $15^{\text {th }}$ English Profile seminar at Cambridge. The presentation, entitled "Comparing pragmatic profiles of native speakers and foreign language learners of English", exemplarily covered both a comparison between the more recently-added Canadian native speaker data and other varieties, as well as the learner data, contrasted with all native speaker varieties covered in PRA.PRO to date. Looking at data from a small-talk DPT, the findings show that, whereas Canadian pragmatic behaviour is highly similar to the English English profile, the German learners of English behave more like native speakers of American English, in this particular communicative situation. Looking at the development of pragmatic competence over their stay abroad, the results, for example, showed that, while responses to thanks elicited from the German learners did not fully attune to the Canadian native speaker norm, use of "anytime" rose from $0.8 \%$ to $15.8 \%$ over the full ten month in Canada, thus approximating the fre- 
quency in Canadian native speakers' responses to thanks at 20\%. Based on these initial findings, we argued that, while the method used does not elicit actual behaviour, but behavioural norms represented in the language users' minds (cf. Schneider 2011 and $2012 \mathrm{~b}$ ), it nonetheless allows us to assess the development of pragmatic competence in English as a foreign language from a data-driven perspective.

Future plans for PRA.PRO include the gathering of further learner data over extended stays abroad, again with the support of Stepin, to provide a more solid empirical basis for developmental analyses. Furthermore, an upcoming project strand will extend the methodological range and triangulate earlier results, by testing them in a perceptional format, eliciting meta-pragmatic judgments from native speakers. This method has already been applied in a parallel research project called EEE (Emerging Email Etiquette), investigating pragmatic norms and recipient expectations in computer-mediated communication, more specifically in email communication between students and university staff (see Schneider 2013). In adopting this method for PRA.PRO, we want to make sure that our interpretation of learner production diverging from native speaker norms actually maps onto judgments of appropriateness in lay perception which is, after all, the most realistic yardstick of communicative success in actual intercultural encounters between learners and native speakers, an issue that both we and the CEFR are centrally concerned with.

\section{CONCLUSION}

In the present paper, we have outlined a number of challenges that the CEFR will have to face in order to eventually transform the language education landscape, according to its proclaimed vision of communicative competence. While we are pleased to see that the theory of language learning and linguistic competence it advocates broadly reflects the theoretical advances made in linguistic pragmatics over the last few decades, we are also concerned that merely stressing the importance and desirability of pragmatic competence will not automatically lead to advances in practice. Results from our research project, PRA.PRO, can contribute to this enterprise, in that it aims at establishing pragmatic norms for specific varieties of English, in a format that allows for direct comparison with learner performance.

Work on PRA.PRO is still ongoing, but as the project generates further findings, we expect to assemble a catalogue of appropriate native speaker behaviour across a range of representative communicative situations that will eventually result in a proper "pragmatic profile" for the respective variety. Comparing learner performance with these established norms will offer a new metric for assessing developing pragmatic competence that goes beyond correct-incorrect distinctions and intuitive expert ratings. We hope that continued collaboration with the English Profile group will enable us to bring these advances to the attention of the European Council and other institutions concerned with the further development and implementation of the CEFR. If a functional, communicative perspective is to become the driving force behind language learning, teaching and testing as the CEFR claims, then we need to ensure that practi- 
tioners have access to both the information and resources necessary to transform their practices accordingly.

We would like to thank Hannah Aengenvoort for her work on PRA.PRO.

\section{References}

ALCÓN SOLER, Eva/Alica MARTÍNEZ-FLOR (eds) (2008) Investigating Pragmatics in Foreign Language Learning, Teaching and Testing. Bristol/Buffalo/Toronto: Multilingual Matters.

BACHMANN, Lyle (1990) Fundamental Considerations in Language Testing. Oxford: Oxford University Press.

BALL, Martin (2000) "Problems in pragmatic profiling." In: N. Müller (ed.), 89-106.

BARDOVI-HARLIG, Kathleen/Rebecca MAHAN-TAYLOR (2003) "Introduction to teaching pragmatics." English Teaching Forum 41/3, 37-44.

BARRON, Anne (2003) Acquisition in Interlanguage Pragmatics: learning how to do things with words in a study abroad context. Amsterdam/Philadelphia: Benjamins.

BARRON, Anne (2005) "Variational pragmatics in the foreign language classroom." System 33/3, 519-536.

BARRON, Anne/Klaus P. SCHNEIDER (eds) (2005) The Pragmatics of Irish English. Berlin: Mouton de Gruyter.

BLOOM, Ronald L./Loraine K. OBLER/Susan DE SANTI/Jonathan S. EHRLICH (eds) (1994) Discourse Analysis and Applications: studies in adult clinical populations. Hillsdale: Erlbaum.

BURWITZ-MELZER, Eva/Wolfgang HALLET/Michael K. LEGUTKE/Franz-Joseph MEISSNER/Joybrato MUKHERJEE (eds) (2008) Sprachen lernen - Menschen bilden [Beiträge zur Fremdsprachenforschung 10]. Baltmannsweiler: SchneiderVerlag Hohengehren.

BYRAM, Michael (1997) Teaching and Assessing Intercultural Communicative Competence. Clevedon: Multilingual Matters.

BYRAM, Michael (2004) INCA The Theory. European Commission. 10 October 2014. http://ec.europa.eu/ewsi/UDRW/images/items/docl_9372_399031269.pdf.

Common European Framework of Reference for Languages: Learning, Teaching, Assessment (2001). Cambridge: Cambridge University Press.

CULPEPER, Jonathan (2012) “( $\mathrm{Im})$ politeness: three issues.” Journal of Pragmatics 44, 1128-1133.

FRASER, Bruce (2010) "Pragmatic competence: the case of hedging." In: G. Kaltenböck/W. Mihatsch/S. Schneider (eds), 15-34.

GREEN, Anthony (2012) Language Functions Revisited: theoretical and empirical bases for language construct definition across the ability range. Cambridge: Cambridge University Press.

HOLMES, Janet/Dorothy BROWN (1987) "Teachers and students learning about compliments." TESOL Quarterly 21/3, 523-546. 
IFANTIDOU, Elly (2010) “Genres and pragmatic competence." Journal of Pragmatics 43/1, 327-346.

Introductory Guide to the Common European Framework of Reference [CEFR] for English Language Teachers. Cambridge: Cambridge University Press. 10 June 2014. http://n.b5z.net/i/u/10177028/f/GuideToCEFR.pdf.

JUCKER, Andreas H. (2008) "Historical pragmatics." Language and Linguistics Compass 2/5, 894-906.

KALTENBÖCK, Gunther/Wiltrud MIHATSCH/Stefan SCHNEIDER (eds) (2010) New Approaches to Hedging. Bingley: Emerald.

KASPER, Gabriele (1995) "Wessen Pragmatik? Für eine Neubestimmung fremdsprachlicher Handlungskompetenz." Zeitschrift für Fremdsprachenforschung 6, $1-25$.

KASPER, Gabriele/Steven ROSS (2013) "Assessing second language pragmatics: theoretical perspectives.” In: S. Ross/G. Kasper (eds), 1-40.

KECSKES, Istvan (2014) Intercultural Pragmatics. Oxford: Oxford University Press.

LAMAR, Mary A. C./Loraine K. OBLER/Janice KNOEFEL/Martin L. ALBERT (1994) "Communication patterns in end-stage Alzheimer's Disease: pragmatic analyses." In: R. L. Bloom/L. K. Obler/S. De Santi/J. S. Ehrlich (eds), 217-235.

LÁZÁR, Ildikó/Martina HUBER-KRIEGLER/Denise LUSSIER/Gabriela S. MATEI/ Christiane PECK (eds) (2007) Developing and Assessing Intercultural Communicative Competence: a guide for language teachers and teacher educators. Strasbourg/ Graz: European Centre for Modern Languages and Council of Europe Publishing.

LEECH, Geoffrey (1983) Principles of Pragmatics. London: Longman.

LEHMANN, Winfred P./Yakov MALKIEL (eds) (1968) Directions for Historical Linguistics: a symposium. Austin: University of Texas Press.

LIU, Jianda (2004) Measuring Interlanguage Pragmatic Knowledge of Chinese EFL Learners. PhD dissertation. City University of Hong Kong.

MARTYNIUK, Waldemar/José NOIJONS (2007) Executive Summary of Results of a Survey on the Use of the CEFR at National Level in the Council of Europe Member States. 22 May 2014. http://www.coe.int

McNAMARA, Tim/Carsten ROEVER (1996) Language Testing: the social dimension. Malden: Blackwell.

MÜLLER, Nicole (ed.) (2000) Pragmatics and Clinical Applications. Amsterdam: Benjamins.

NORTH, Brian (2014) "Putting the Common European Framework of Reference to good use." Language Teaching 47, 228-249.

O'KEEFFE, Anne/Brian CLANCY/Svenja ADOLPHS (2011) Introducing Pragmatics in Use. London: Routledge.

REGAN, Vera/Martin HOWARD/Isabelle LEMÉE (2009) The Acquisition of Sociolinguistic Competence in a Study Abroad Context. Bristol/Buffalo/Toronto: Multilingual Matters.

ROSS, Steven/Gabriele KASPER (eds) (2013) Assessing Second Language Pragmatics. Basingstoke: Palgrave Macmillan. 
RÖDER, Katrin/Ilse WISCHER (eds) (2013) Anglistentag 2012 Potsdam: proceedings. Trier: Wissenschaftlicher Verlag Trier.

SCHIFFRIN, Deborah (1987) Discourse Markers. Cambridge: Cambridge University Press.

SCHAUER, Gila A. (2009) Interlanguage Pragmatic Development: the study abroad context. London: Continuum.

SCHNEIDER, Klaus P. (2005) “"No problem, you're welcome, anytime': responding to thanks in Ireland, England, and the U.S.A." In: A. Barron/K. P. Schneider (eds), 101-139.

SCHNEIDER, Klaus P. (2008a) "Small talk in England, Ireland, and the U.S.A.” In: K. P. Schneider/A. Barron (eds), 99-139.

SCHNEIDER, Klaus P. (2008b) "Teaching intercultural competence and pragmatic variation.” In: E. Burwitz-Melzer/W. Hallet/M. K. Legutke/F.-J. Meißner/J. Mukherjee (eds), 179-189.

SCHNEIDER, Klaus P. (2011) "Imagining conversation: how people think people do things with words." Sociolinguistic Studies 5/1, 15-36.

SCHNEIDER, Klaus P. (2012a) "Appropriate behaviour across varieties of English." In: M. Haugh/K. P. Schneider (eds), Im/politeness Across Englishes. Special Issue. Journal of Pragmatics 44/9, 1022-1037.

SCHNEIDER, Klaus P. (2012b) "Pragmatic variation and cultural models." Review of Cognitive Linguistics 10/2, 346-372.

SCHNEIDER, Klaus P. (2013) "Emerging e-mail etiquette: lay perceptions of appropriateness in electronic discourse.” In: K. Röder/I. Wischer (eds), 329-340.

SCHNEIDER, Klaus P./Anne BARRON (2008a) "Where pragmatics and dialectology meet: introducing variational pragmatics.” In: K. P. Schneider/A. Barron (eds), $1-32$.

SCHNEIDER, Klaus P./Anne BARRON (eds) (2008b) Variational Pragmatics: a focus on regional varieties in pluricentric languages. Amsterdam/Philadelphia: Benjamins.

TAGUCHI, Naoko (2011) "The effect of L2 proficiency and study-abroad experience on pragmatic comprehension." Language Learning 61/3, 904-939.

THOMAS, Jenny (1983) “Cross-cultural pragmatic failure." Applied Linguistics 4/2, 91-112.

WEINREICH, Uriel/Wiliam LABOV/Marvin HERZOG (1968) "Empirical foundations for a theory of language change." In: W. Lehmann/Y. Malkiel (eds), 95-195.

WIERZBICKA, Anna (1985) "Different culture, different languages, different speech acts." Journal of Pragmatics 9, 145-178.

YAMASHITA, Sayoko (2008) "Investigating interlanguage pragmatic ability: what are we testing?” In: E. Alcón Soler/A. Martínez-Flor (eds), 201-223.

YULE, George (1996) Pragmatics. Oxford: Oxford University Press. 


\section{Abstract \\ PRAGMATIC COMPETENCE AND THE CEFR: PRAGMATIC PROFILING AS A LINK BETWEEN THEORY AND LANGUAGE USE}

The functional and communicative perspective on language advocated in the Common European Framework of Reference for Languages (CEFR), hides the fact that, while the CEFR programmatically emphasises the role of pragmatic competence in language learning, it provides little guidance in how to transform the domain of language learning, teaching and testing, accordingly. In the present paper, we argue for an extended and more detailed treatment of pragmatic competence in the context of the CEFR, that we think is necessary to enable practitioners to implement this conception of communicative competence in their everyday work. Whereas a gap between the CEFR's programmatic vision and practical requirements has been noted and addressed, e.g. by the creation of reference level descriptions (RLDs) for individual languages, the pragmatic component has thus far not been thoroughly covered by the respective initiatives, such as the English Profile.

Based on a review of definitions of pragmatic competence in the linguistic literature, we claim that a customised methodology will be necessary to fully integrate pragmatic competence into CEFR-based descriptions of language competence, especially if these descriptions are to be operationalised in language testing and certification. We then present our own approach to the issue of assessing pragmatic competence, which is part of an ongoing research project called Pragmatic Profiling (PRA.PRO). One of the main goals of this project is to establish pragmatic profiles of different varieties of English based on native speaker communicative behaviour, elicited via a variety of tasks in a standardized questionnaire format (the Questionnaire on English Usage), and other methods. The pragmatic norms derived from this empirical data can be directly compared with learner performance, which will ultimately allow us to assess divergence from native speaker norms and, thereby, evaluate levels of developing pragmatic competence in learners. Our primary concern is to point out that more empirical research is needed to link the levels of theoretical description and concrete communicative performance, and that the methodology employed in PRA.PRO is a promising route to achieving this goal.

Keywords: pragmatic competence assessment, cultural norms, learners of English, appropriateness, native speaker behaviour. 


\section{Povzetek \\ PRAGMATIČNA ZMOŽNOST IN SEJO: PRAGMATIČNO PROFILIRANJE KOT VEZ MED TEORIJO IN JEZIKOVNO RABO}

Funkcijska in komunikacijska perspektiva, ki jo zagovarja Skupni evropski jezikovni okvir (SEJO), prikriva dejstvo, da SEJO navkljub načrtnemu poudarjanju pragmatične zmožnosti pri učenju jezika ponuja le malo napotkov za hkratno spremembo jezikovnega učenja, poučevanja in testiranja. $\mathrm{V}$ prispevku se avtorja zavzemata za bolj poglobljeno in natančnejšo obravnavo pragmatične kompetence, kakršna je po njunem mnenju za praktike pri uporabi koncepta komunikacijske kompetence pri njihovem vsakodnevnem delu nujna. Medtem ko je bila vrzel med programsko vizijo Skupnega evropskega jezikovnega okvira in praktičnimi potrebami že zaznana in obravnavana, npr. pri sestavljanju opisnikov za referenčne stopnje za posamezne jezike, pa pragmatične komponente ustrezne pobude - kot npr. English Profile - še niso ustrezno obravnavale.

Po pregledu definicij pragmatične kompetence $v$ jezikoslovni literaturi avtorja trdita, da bo za popolno vključitev pragmatične zmožnosti v opisnike jezikovne kompetence potrebna prilagojena metodologija, še posebej, kadar so ti opisniki namenjeni uporabi pri testiranju in certificiranju. V nadaljevanju članka predstavljava svoj pristop k vrednotenju pragmatične kompetence; gre za del projekta z naslovom Pragmatično profiliranje (Pragmatic Profiling, PRA.PRO). Eden od ključnih ciljev projekta je vzpostavitev pragmatičnih profilov za različne zvrsti angleščine, ki bi temeljili na komunikacijskih vzorcih naravnih govorcev in bi bili pridobljeni na različne načine, npr. s standardiziranim vprašalnikom in drugimi metodami. Pragmatične norme, izpeljane iz empiričnih podatkov, lahko takoj primerjamo z dosežki učencev, to pa nam omogoči primerjavo z normo rojenega govorca in $s$ tem oceno stopnje razvoja pragmatične kompetence učenca. Predvsem želita poudariti, da potrebujemo za povezavo med teoretičnim opisom ravni in konkretnim komunikacijskim dosežkom empirične raziskave in da se na poti do zastavljenega cilja metodologija, uporabljena v projektu PRA.PRO, zdi obetavna.

Ključne besede: vrednotenje pragmatične kompetence, kulturne norme, učenci angleščine, primernost, obnašanje rojenega govorca. 